\title{
Hydrologic Response of a Central Nevada Pinyon-Juniper Woodland to Prescribed Fire
}

\author{
Benjamin M. Rau, ${ }^{1}$ Jeanne C. Chambers, ${ }^{2}$ Robert R. Blank, ${ }^{3}$ \\ and Wally W. Miller ${ }^{4}$ \\ Authors are ${ }^{1}$ Graduate Research Assistant, Hydrologic Sciences, University of Nevada, Reno, Reno, NV 89512; \\ ${ }^{2}$ Research Ecologist, USDA Forest Service-Rocky Mountain Research Station, Great Basin Ecology Lab, Reno, NV 89512; \\ ${ }^{3}$ Soil Scientist, USDA-ARS Invasive Weed Lab, Reno, NV 89512; and ${ }^{4}$ Professor of Hydrologic Sciences, \\ University of Nevada, Reno, Reno, NV 89512.
}

\begin{abstract}
This study was conducted to determine the effect of prescribed fire on surface hydrology in Great Basin pinyon-juniper (Pinus monophylla Torr. \& Frém.-Juniperus osteosperma Torr.) woodlands. Infiltration rates were measured using a single ring infiltrometer over an elevation gradient $(2103,2225$, and $2347 \mathrm{~m})$ at 3 microsites (tree canopy, shrub canopy, and interspace) and 2 tree cover types (intermediate and high) in August 2001, before a spring prescribed burn conducted in May 2002, and then following the prescribed burn in August 2002. Infiltration experiments were used to calculate saturated hydraulic conductivity $\left(\mathrm{K}\left[\theta_{\mathrm{s}}\right]\right)$ rates, and water drop penetration times were determined to evaluate the development of water-repellent soils. Infiltration rates before the burn were greater at the low elevation than at the mid and high-elevation study sites because of differences in measured soil texture. Before burning, the infiltration and saturated hydraulic conductivity $\left(K\left[\theta_{s}\right]\right)$ rates measured on interspace and shrub canopy microsites were less than on tree canopy microsites at the midelevation study site $(2225 \mathrm{~m})$. Following burning, the intermediate tree cover tree canopy microsites had greater infiltration rates than interspace microsites; all other microsites were similar to each other. No significant differences in $K\left(\theta_{\mathrm{s}}\right)$ rates existed among the microsites after burning. However, on the higher elevation study site before the burn, the interspace microsites had final infiltration rates less than the tree canopy microsites, and burning caused no deviation from this trend. Saturated hydraulic conductivity rates at the high elevation did not differ by microsite before the burn, but after burning interspace microsites had $K\left(\theta_{s}\right)$ rates less than tree canopy microsites. Burning increased water repellency of surface soils $(0-3 \mathrm{~cm})$ for all cover types. Spring burning in Pinyon-juniper woodlands may produce a hydrologic response depending on surface soil texture and vegetation cover.
\end{abstract}

\section{Resumen}

Este estudio se condujo para determinar el efecto del fuego prescrito en la hidrología superficial en los bosques de "PinyonJuniper" (Pinus monophylla Torr. \& Frém.-Juniperus osteosperma Torr.) de la Gran Cuenca. Las tasas de infiltración fueron medidas usando un infiltrometro de un anillo a lo largo de un gradiente de elevación (2 103, 2225 , y $2347 \mathrm{~m})$ en 3 micrositios (copa de árbol, copa de arbusto, y espacio entre plantas) y en dos tipos de copa de árbol (intermedia y alta). Las mediciones de infiltración se realizaron en Agosto del 2001, antes de un fuego prescrito de primavera conducido en Mayo del 2002, y después del fuego prescrito en Agosto de del 2002. Los experimentos de infiltración fueron usados para calcular las tasas de conductividad hidráulica saturada $\left(\mathrm{K}\left[\theta_{\mathrm{s}}\right]\right)$ y los tiempos de penetración de las gotas de agua se determinaron para evaluar el desarrollo de suelos repelentes al agua. Las tasas de infiltración antes del fuego fueron mayores en la elevación baja que en los sitos de estudio de las elevaciones media y alta, debido a diferencias en la textura del suelo. Antes de la quema, en el sitio de estudio de elevación media $(2225 \mathrm{~m})$, las tasas de infiltración y conductividad hidráulica saturada $\left(\mathrm{K}\left[\theta_{\mathrm{s}}\right]\right)$ de los micrositios de espacio entre plantas y copa de arbustos fueron menores que las del microsito de copa del árbol. Después de la quema, los micrositios de copa de árbol intermedia tuvieron mayores tasas de infiltración que los micrositios de espacio entre plantas, todos los otros sitios fueron similares entre si. Después de la quema no hubo diferencias significativas en las tasas de $\mathrm{K}\left(\theta_{\mathrm{s}}\right)$ entre los micrositios. Sin embargo, antes de la quema, en el sitio de estudio de elevación alta, los micrositios de espacio entre plantas tuvieron tasas de infiltración final menores que los micrositios de copa de árbol y la quema no causo desviaciones de esta tendencia. Las tasas de conductividad hidráulica saturada en la elevación alta no difirieron por micrositio antes de la quema, pero después de ella, los micrositios de espacio entre plantas tuvieron tasas de $\mathrm{K}\left(\theta_{\mathrm{s}}\right)$ menores que los micrositios de copa de árbol. La quema incrementó la repelencia del agua de la superficie de los suelos $(0-3 \mathrm{~cm})$ en todos los tipos de cobertura. La quema en primavera de los bosques de "Pinyon-Juniper" puede producir una respuesta hidrológica dependiente de la textura de la superficie del suelo y la cobertura vegetal.

Key Words: surface hydrology, water repellency, coarse fragment, microsite

Research was funded by the US Dept of Agriculture Forest Service—Rocky Mountain Research Station, Great Basin Ecosystem Management Project, and Joint Fire Sciences Program Project 0TB-3-3-01.

Correspondence: Benjamin Rau, Hydrologic Sciences Program, University of Nevada, Reno, Reno, NV 89512. Email: brau@unr.nevada.edu

Manuscript received 11 July 2004; manuscript accepted 1 September 2005. 


\section{INTRODUCTION}

Pinyon-juniper (Pinus monophylla Torr. \& Frém.-Juniperus osteosperma Torr.) woodlands in the Great Basin currently occupy about 18 million ha (Miller and Tausch 2001), an increase of roughly $60 \%$ to $94 \%$ from the area occupied before European settlement, approximately 140 years ago (Gruell 1999). Although pinyon-juniper woodlands have expanded and receded several times over the last 5000 years, the rate of expansion over the last 140 years is unprecedented, and less than $10 \%$ of current woodlands are older than 140 years (Miller and Tausch 2001). Before European settlement, wildfire return intervals were 25 to 130 years, restricting woodlands to steep rocky terrain with limited understory vegetation. These fire-resistant sites currently retain woodlands of age classes older than 140 years (Miller and Tausch 2001). Domestic livestock grazing, warming at the end of the little ice age, and fire suppression explain current woodland expansion (Miller and Wigand 1994; Miller and Rose 1995, 1999).

Increasing tree dominance and crown cover eliminates understory vegetation, and increases crown fuel continuity across the landscape (Tausch 1999a, 1999b). Crown cover exceeding $50 \%$ is sufficient to carry high-intensity fire during dry or windy periods. Woodlands with this coverage now occupy $25 \%$ of the current area, and are expected to double over the next 50 years (Miller and Tasusch 2001).

High-severity wildfires have been reported to produce increased hydrologic responses in arid and semiarid woodland ecosystems (Covington and DeBano 1990). Illg and Illg (1997) and Cannon et al. (1998) have reported increased water repellency, flooding, and debris flows following wildfire in ponderosa pine (Pinus ponderosa P. \& C. Lawson) forest. Poff (1989) has found severe water repellency in white fir (Abies concolor [Gord. \& Glend.] Lindl. ex Hildebr.) forest after wildfire, and Pierson et al. (2001, 2002) described decreased infiltration and increased sediment yield in sagebrush-steppe following wildfire. Little information regarding postwildfire surface hydrology has been reported in pinyon-juniper woodlands where landscape response to fire is highly dependent on the timing of precipitation. In the Southwest, for example, a late spring fire season is followed by the summer monsoon, characterized by short-duration, high-intensity rainfall (Mohrle 2003). By contrast, in the Great Basin, most fires occur in late summer, and precipitation comes primarily as winter snow and spring rains.

Infiltration rates are often high in mature pinyon-juniper woodlands, but prescribed burning can reduce infiltration and increase sediment yield (Buckhouse and Gifford 1976). The effects of prescribed fire on infiltration and runoff may be less pronounced in pinyon-juniper than in other cover types such as oak (Quercus virginiana P. Mill.), bunchgrass, and shortgrass (Hester et al. 1997). Burning can have variable effects on soil hydrologic response based on fire severity and antecedent soil and fuel moisture content (DeBano 2000). Pinyon-juniper woodlands are spatially heterogeneous, and undershrub and undertree canopy microsites tend to have more litter and soil organic carbon than interspace microsites (Davenport et al. 1998, Chambers 2001). Burning volatilizes organic hydrocarbon compounds, which are often drawn into the soil profile due to steep temperature gradients, and condense onto soil particles creating a water repellent layer (DeBano et al. 1970). The depth and extent to which water repellent conditions develop is determined by soil moisture and soil-specific surface area (DeBano et al. 1970, 1976). Pinyon-juniper woodlands occur in areas of variable particle size dependent on landscape position and relief (Davenport et al. 1998; D. Zamudio, USDA Soil Scientist, Lakeview, Oregon, personal communication, 2001).

Burning may also alter soil hydrologic properties by the addition of ash to the soil. Ash may fill small soil pores, or cause dispersion of expandable clays by increasing potassium carbonate (Durgin 1985). Intense burning may reduce soil elasticity and plasticity by consumption of organic matter and formation of coarse-grained silica aggregates (Ulery and Graham 1993; Ulery et al. 1996).

Prescribed fire has been suggested as a management tool to decrease pinyon-juniper expansion and reduce the risk of highseverity wildfire. In this study we investigate the soil hydrologic response (water repellency, final infiltration rate, and saturated hydraulic conductivity) of a pinyon-juniper woodland to a prescribed burn. Specific objectives were 1) to determine the hydrologic response of soil over the typical elevation gradient found in pinyon-juniper woodlands, and 2) determine how spatial variability and cover type within woodlands affect the soil's hydrologic response to burning.

\section{MATERIALS AND METHODS}

\section{Study Area}

The study area is located in the Shoshone Mountain Range on the Humboldt-Toiyabe National Forest (Austin Ranger District) in Nye and Lander Counties, Nevada. Underdown Canyon (lat $39^{\circ} 15^{\prime} 11^{\prime \prime} \mathrm{N}$, long $117^{\circ} 35^{\prime} 83^{\prime \prime} \mathrm{W}$ ) is oriented east to west and contains infrequent springs and an ephemeral stream near the top of the drainage. Average annual precipitation ranges from $230 \mathrm{~mm}$ at the bottom to $500 \mathrm{~mm}$ at the top of the drainage, and arrives primarily in winter as snow and spring rains (USDA Forest Service Rocky Mountain Research Station [RMRS], Reno, Nevada, unpublished data). Average annual temperature recorded in Austin, Nevada, ranges from $-7.2^{\circ} \mathrm{C}$ in January to $29.4^{\circ} \mathrm{C}$ in July. Lithology of the Shoshone range consists of welded and nonwelded silica ash flow tuff. Soils developed on alluvial fans in this study are classified as Coarse loamy mixed frigid Typic Haploxerolls. Coarse mineral particles and silt decease and sand particles generally increase with increasing elevation (Table 1). The slope of these sidevalley alluvial fans ranges from $5 \%$ to $20 \%$.

Vegetation is dominated by single-leaf pinyon (Pinus monophylla Torr. \& Frém.) and associated sagebrush (Artemisia tridentata Nutt.) communities. Utah juniper (Juniperus osteosperma Torr.) occurs in minor amounts throughout the study area. Wyoming sagebrush (Artemisia tridentata wyomingensis Beetle \& Young), Sandberg bluegrass (Poa secunda secunda J. Presl), squirrel tail (Elymus elymoides Swezey), and needle and thread grass (Stipa comata Trin. \& Rupr.) dominate lower elevations. Mountain big sagebrush (Artemisia tridentata ssp vaseyana [Rydb.] Boivin) occurs at mid to high elevations, as does Idaho fescue (Festuca idahoensis Elmer) and bluebunch wheatgrass (Pseudoroegneria spicata [Pursh] A. Löve). Forbs in the study area include Erioginum species, western hawksbeard 
(Crepis acuminata Nutt.), longleaf phlox (Phlox longifolia Nutt.), pale agoseris (Agoseris glauca [Pursh] Raf.), tailcup lupine (Lupinus argenteus Pursh), Penstemon species, and others in less abundance. Cheatgrass (Bromus tectorum L.), an invasive annual grass, is not a large component of the study area.

The vegetation occurs in patches of variable tree dominance and is classified as low $\left(12 \%\right.$ cover, $\left.2152 \mathrm{~kg} \cdot \mathrm{ha}^{-1}\right)$, intermediate $\left(38 \%\right.$ cover, $\left.6722 \mathrm{~kg} \cdot \mathrm{ha}^{-1}\right)$, and high tree dominance $\left(74 \%\right.$ cover, $\left.14213 \mathrm{~kg} \cdot \mathrm{ha}^{-1}\right)$ (Reiner 2004).

\section{Study Design}

The study was a nested design with subsampling. The study sites were located on northeast-facing alluvial fans at elevations of 2103,2225 , and $2347 \mathrm{~m}$. Three plots were sampled at each elevation. Plots were characterized by intermediate tree dominance at all elevations $(n=9)$ with 3 additional high treedominance plots occurring at the 2225 -m study site. All plots measured approximately $1000 \mathrm{~m}^{2}$ and contained a mixture of trees, shrubs, and interspaces. Two subsamples were located in each of 3 microsites (shrub canopy, tree canopy, and interspace) on all plots except for the high tree-dominance plots where only the tree canopy microsite was sampled $(n=60)$. USDA Forest Service fire personnel burned the study plots on 11-14 May 2002 under favorable weather conditions (air temperature $<32^{\circ} \mathrm{C}$, relative humidity $>15 \%$, wind speed $<9 \mathrm{~m} \cdot \mathrm{s}^{-1}$, and gravimetric fuel moisture $\approx 40 \%$ ). Maximum soil temperatures were recorded during the fire using heat-sensitive paints on metal strips with a range of $39^{\circ}-788^{\circ} \mathrm{C}$ in $28^{\circ} \mathrm{C}$ increments. Strips were placed parallel to the soil surface at $0-, 2-$, and $5-\mathrm{cm}$ soil depths at all microsites (Korfmacher et al. 2002).

\section{Field Data Collection}

To characterize the soil, pits were dug at all 3 elevations. Soil horizons were identified and samples were collected for particle size analyses (Table 1). Samples were sieved to $2 \mathrm{~mm}$, organic matter was removed with $\mathrm{H}_{2} \mathrm{O}_{2}$, and particle size distribution was determined by the pipette method (Black 1965).

Infiltration was measured using a 345-mm-diameter Single Ring Infiltrometer (SRI) before the burn in August 2001 and again in August 2002 following the prescribed burn $(n=120)$. The ring was placed at each microsite (tree canopy, shrub canopy, and interspace) so that the soil surface was not disturbed. The ring was inserted into the mineral soil surface to a depth of approximately $50 \mathrm{~mm}$ on localized slopes from $0 \%$ to $10 \%$. A Scotch ${ }^{\mathrm{TM}}$ pad was placed in the center of the ring and $2 \mathrm{~L}$ of water were poured onto the pad in order to prewet the soil and prevent dispersion at the soil surface. Water was then ponded to a depth of $20 \mathrm{~mm}$ in the center of the ring and maintained for the duration of the test. Volume measurements of water added were taken every 2 minutes for 30 minutes (Bouwer 1986). Cumulative infiltration $\left(\mathrm{I}=\mathrm{mm}^{3} \cdot \mathrm{mm}^{-2}\right)$ was plotted against time $(t)$. After the first year, it was determined that the slope of I vs. $t$ rapidly reached a constant value such that it could be obtained by shortening the total test time from 30 to 16 minutes. By plotting the slope $(\Delta \mathrm{I} / \Delta \mathrm{t})$ between each measurement interval over time $\left(\mathrm{mm} \cdot \mathrm{min}^{-1}\right.$ vs. time) a standard infiltration curve (i vs. $t$ ) was obtained. Because $i$ was not constant, final infiltration rates $\left(\mathrm{i}_{\mathrm{f}}\right)$ for each experiment were
Table 1. Particle sizes of soils at elevations of $2103 \mathrm{~m}, 2225 \mathrm{~m}$, and $2347 \mathrm{~m}$

\begin{tabular}{|c|c|c|c|c|}
\hline Depth $(\mathrm{cm})^{1}$ & $>2 \mathrm{~mm} \%^{2}$ & Sand $\%^{3}$ & Silt $\%^{3}$ & Clay $\%^{3}$ \\
\hline \multicolumn{5}{|c|}{ - } \\
\hline $0-15 \mathrm{~A}$ & 73.7 & 53.2 & 44.1 & 2.7 \\
\hline $15-50 \mathrm{AB}$ & 72.0 & 52.3 & 43.3 & 4.4 \\
\hline $50-70 B_{w}$ & 81.7 & 63.6 & 31.0 & 5.4 \\
\hline $70-100 \mathrm{BC}$ & 75.0 & 64.4 & 33.5 & 2.1 \\
\hline $0-16 A_{1}$ & 59.7 & 67.6 & 23.9 & 8.5 \\
\hline $16-28 \mathrm{~A}_{2}$ & 55.3 & 59.3 & 33.5 & 7.2 \\
\hline $28-40 \mathrm{BA}$ & 47.8 & 65.9 & 27.1 & 7.1 \\
\hline $40-70 B_{w}$ & 47.0 & 53.9 & 21.4 & 24.6 \\
\hline $70-100 \mathrm{BC}$ & 31.1 & 64.5 & 24.8 & 10.7 \\
\hline $0-15 A_{1}$ & 42.8 & 67.6 & 24.9 & 7.5 \\
\hline $15-38 \mathrm{~A}_{2}$ & 35.3 & 62.9 & 30.9 & 6.2 \\
\hline $38-65 B_{w}$ & 53.7 & 63.2 & 29.0 & 7.8 \\
\hline $65-100 \mathrm{BC}$ & 55.9 & 65.1 & 29.8 & 5.1 \\
\hline
\end{tabular}

${ }^{1}$ Letters following soil depth refer to the soil horizon nomenclature.

${ }^{2}$ Represents $>2 \mathrm{~mm} \%$ of the total soil.

${ }^{3}$ The sand, silt, and clay percentages make up $100 \%$ of the $<2 \mathrm{~mm}$ soil fraction.

obtained by taking the mean value of the 10 - to 16 -minute intervals (Pierson et al. 2002).

A subset of soil samples was collected from the intermediate elevation $(2225 \mathrm{~m})$ study site in order to assess the development of water repellency. Soils were collected 2 days before the burn from all plots and microsites at depths of 0-3 and $3-8 \mathrm{~cm}(n=24)$. Collection sites were marked with a metal stake so that they were easily located after the prescribed burn. Samples were again collected 2 days after the burn from the same locations $(n=24)$. Soils were brought back to the lab, air dried, and sieved to $2 \mathrm{~mm}$. Water drop penetration times (WDPTs) were performed by pipetting 1 drop of water onto each soil sample's surface (Letey 1969). The time for each drop to be absorbed onto the soil was recorded with a minimum and maximum value of 1 and 180 seconds, respectively. Three replicates were performed on each sample $(n=144)$.

\section{Theory}

Saturated hydraulic conductivity $\mathrm{K}\left(\theta_{\mathrm{s}}\right)$ rate $\left(\mathrm{mm} \cdot \mathrm{min}^{-1}\right)$ was estimated when there was no change in the volume infiltration over time. The following relationship for 1-dimensional saturated infiltration in the vertical direction was applied:

$$
\mathrm{Q} / \mathrm{At}=-\mathrm{K}\left(\theta_{\mathrm{s}}\right)[(\mathrm{z}+\mathrm{p}) / \mathrm{L}]
$$

where $\mathrm{Q} / \mathrm{At}\left(\mathrm{mm}^{3} \cdot \mathrm{mm}^{-2}\right)$ is the measured parameter, $\mathrm{Q}$ is the volume of water flowing per unit of time $\left(\mathrm{mm}^{3} \cdot \mathrm{min}^{-1}\right), \mathrm{A}$ is the cross-sectional area $\left(\mathrm{mm}^{2}\right)$ of the SRI, $t$ is time (in minutes), $\mathrm{K}\left(\theta_{\mathrm{s}}\right)$ is the saturated hydraulic conductivity $\left(\mathrm{mm} \cdot \mathrm{min}^{-1}\right)$, $\mathrm{z}$ is the gravitational potential $(\mathrm{mm}), \mathrm{p}$ is the pressure potential $(\mathrm{mm}), \mathrm{L}$ is the column length $(\mathrm{mm})$, and the change of $\mathrm{z}$ and $\mathrm{p}$ over depth $[(\Delta \mathrm{z}+\Delta \mathrm{p}) / \mathrm{L}]$ is the hydraulic gradient. For vertical infiltration the gravitational gradient $\Delta \mathrm{z} / \mathrm{L}=1$ and 
Table 2. Mean $(n=31)$ maximum soil temperatures and standard errors for surface, 2-, and 5-cm soil depths at all microsites.

\begin{tabular}{|c|c|}
\hline Microsite & Average temperature $\left({ }^{\circ} \mathrm{C}\right)$ \\
\hline \multicolumn{2}{|c|}{ - } \\
\hline Interspace & $206 \pm 24$ \\
\hline Undershrub & $369 \pm 33$ \\
\hline Undertree & $304 \pm 26$ \\
\hline Interspace & $40 \pm 0$ \\
\hline Undershrub & $86 \pm 24$ \\
\hline Undertree & $77 \pm 11$ \\
\hline Interspace & $40 \pm 0$ \\
\hline Undershrub & $40 \pm 0$ \\
\hline Undertree & $44 \pm 3$ \\
\hline
\end{tabular}

as $\mathrm{L}$ approaches infinity the pressure gradient $(\Delta \mathrm{p} / \mathrm{L})$ approaches zero. For long-term saturated vertical infiltration Eq. [1] may then be reduced to

$$
\mathrm{Q} / \mathrm{At}=-\mathrm{K}\left(\theta_{\mathrm{s}}\right)
$$

\section{Statistical Analyses}

Differences in infiltration rate and estimated saturated hydraulic conductivity among elevation, microsites, and dates were evaluated by SAS ${ }^{\mathrm{TM}}$ using mixed effects models (SAS Institute 2004). Elevation was treated as a primary effect, microsite was nested within elevation, and treatment was nested within elevations and microsite. Differences in WDPTs among micro-
Table 3. ANOVA results for WDPTs in pinyon-juniper soils subjected to prescribed burning under different vegetation cover (microsites) at the intermediate elevation (2 $225 \mathrm{~m}$ ) study site.

\begin{tabular}{lrrr}
\hline Factor & df $^{1}$ & $\mathrm{~F}$ & $P$ \\
\hline Microsite & 2 & 1.48 & 0.2785 \\
Replicate $\times$ microsite & 9 & & \\
Depth & 1 & 18.79 & 0.0019 \\
Microsite $\times$ depth & 2 & 1.01 & 0.4007 \\
Replicate $\times$ microsite $\times$ depth & 9 & & \\
Treatment & 1 & 96.28 & $<0.0001$ \\
Treatment $\times$ microsite & 2 & 4.68 & 0.0112 \\
Treatment $\times$ depth & 1 & 37.06 & $<0.0001$ \\
Treatment $\times$ microsite $\times$ depth & 2 & 7.14 & 0.0012 \\
Treatment $\times$ replicate $\times$ microsite $\times$ depth & 111 & & \\
\hline 'Degree of freedom. & & & \\
\hline
\end{tabular}

sites, depth, and dates were also evaluated using the same procedure. Microsite was treated as a primary effect, depth was nested within microsite, and treatment was nested within depths and microsites (SAS Institute 2004). Differences in surface soil coarse fragment were evaluated using a one way analysis of variance (ANOVA) (SAS Institute 2004).

\section{RESULTS}

\section{Soil Heating and Water Repellency}

Soil heating was greatest under shrub canopy microsites at the soil surface and at the $2-\mathrm{cm}$ depth. Tree canopy microsites had slightly lower temperatures, and interspace microsite soils were heated only on the surface (Table 2).

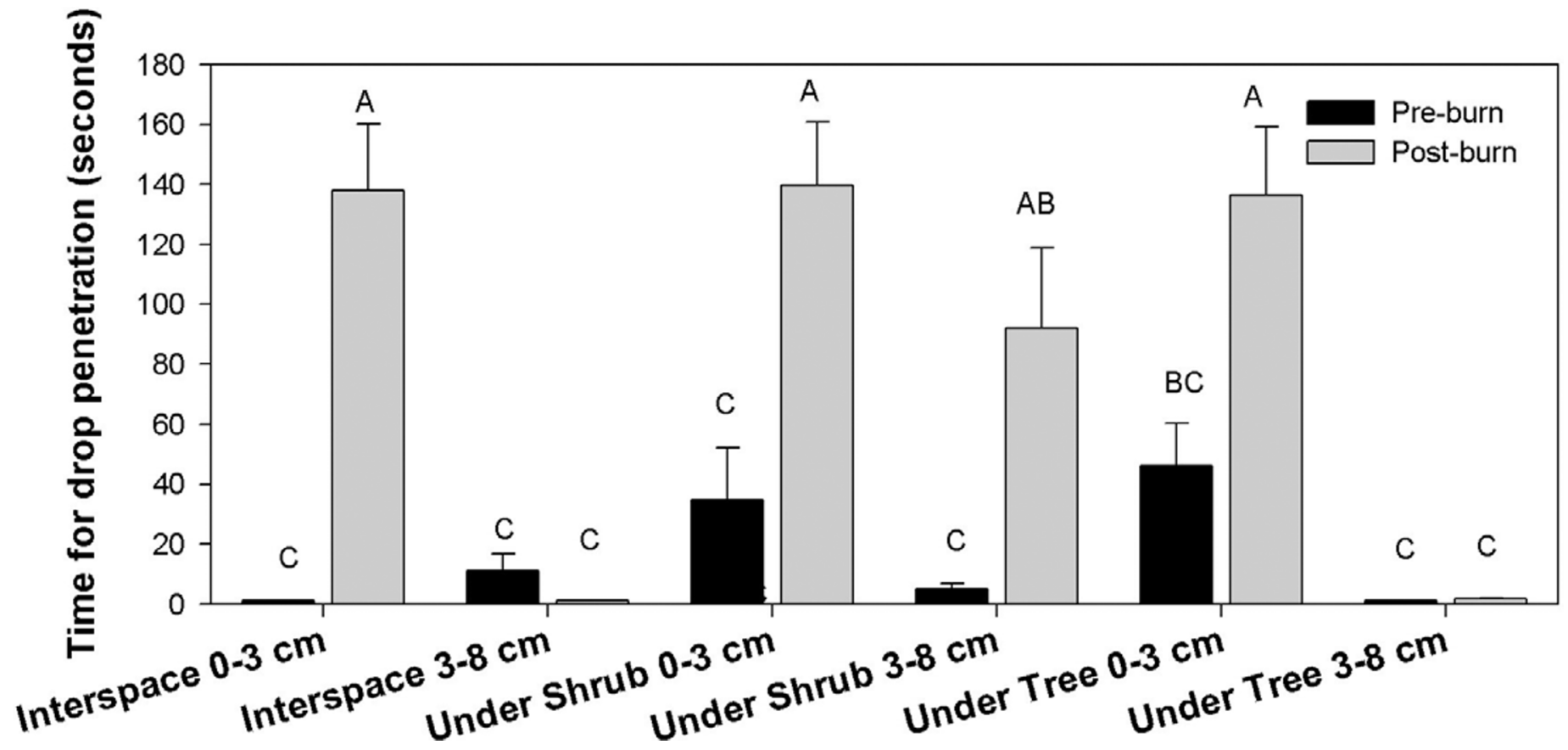

Figure 1. Mean drop penetration times and standard errors before and after prescribed fire for interspace, undershrub, and undertree microsites at 0-3 cm and 3-8 cm. Different letters indicate differences among burn treatment, microsites, and depths (LSM; $P<0.05)$. 
Table 4. Average final infiltration and saturated hydraulic conductivity $\left(K\left[\theta_{s}\right]\right)$ rates $\left(\mathrm{mm} \cdot \mathrm{min}^{-1}\right)$ of pinyon-juniper soils located at different elevations and under different vegetation cover (microsite) before (2001) and after (2002) prescribed burning. Means followed by the same letter within elevations do not differ. (LSM; $P \leq 0.05$ ).

\begin{tabular}{|c|c|c|c|c|c|c|}
\hline \multirow[b]{2}{*}{ Elevation } & \multicolumn{2}{|c|}{$2103 \mathrm{~m}^{1}$} & \multicolumn{2}{|c|}{$2225 \mathrm{~m}$} & \multicolumn{2}{|c|}{$2347 \mathrm{~m}$} \\
\hline & 2001 & 2002 & 2001 & 2002 & 2001 & 2002 \\
\hline \multicolumn{7}{|c|}{ 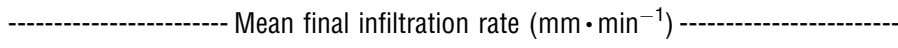 } \\
\hline Intermediate $^{2}$ interspace & 35 & 16 & $4 \mathrm{CD}$ & $5 \mathrm{CD}$ & $4 \mathrm{CD}$ & $3 \mathrm{D}$ \\
\hline Undershrub & 65 & 18 & $8 \mathrm{BC}$ & $9 \mathrm{BC}$ & $7 \mathrm{BCD}$ & $6 \mathrm{BCD}$ \\
\hline Undertree & $\infty^{3}$ & 21 & $18 \mathrm{~A}$ & $10 \mathrm{~B}$ & $9 \mathrm{~B}$ & $10 \mathrm{~B}$ \\
\hline High $^{2}$ undertree & $x^{3}$ & $x$ & $20 \mathrm{~A}$ & $6 \mathrm{BCD}$ & $x$ & $x$ \\
\hline \multicolumn{7}{|c|}{ 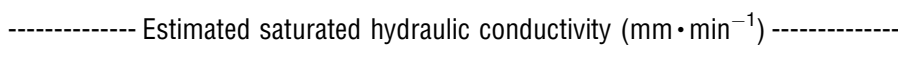 } \\
\hline Intermediate ${ }^{2}$ interspace & 75 & 17 & $5 \mathrm{BC}$ & $5 \mathrm{BC}$ & $5 \mathrm{BC}$ & $4 \mathrm{C}$ \\
\hline Undershrub & 75 & 26 & $8 \mathrm{BC}$ & $9 \mathrm{BC}$ & $7 \mathrm{BC}$ & $6 \mathrm{BC}$ \\
\hline Undertree & $\infty^{3}$ & 25 & $18 \mathrm{~A}$ & $11 \mathrm{~B}$ & $8 \mathrm{BC}$ & $11 \mathrm{~B}$ \\
\hline High $^{2}$ undertree & $x^{3}$ & $x$ & $20 \mathrm{~A}$ & $7 \mathrm{BC}$ & S & $x$ \\
\hline
\end{tabular}

${ }^{1}$ Measurements at the $2103-\mathrm{m}$ study site were not compared statistically.

2The "Intermediate" and "High" headings refer to the stage of tree dominance where the under tree canopy tests were performed.

${ }^{3}$ The symbols " $x$ " and " $\infty$ " refer to microsites that did not occur on the particular study site and inability to pond water on the soil surface, respectively.

WDPTs were affected by depth, burn treatment, treatment $\times$ microsite interactions, treatment $\times$ depth interactions, and treatment $\times$ microsite $\times$ depth interactions (Table 3). The water repellency of the soils was not statistically different for any microsite or depth before the prescribed burn. After the prescribed burn, the surface soil $(0-3 \mathrm{~cm})$ at all microsites exhibited increases in WDPT but microsite differences did not occur (Fig. 1). Subsurface soil $(3-8 \mathrm{~cm})$ remained unchanged by fire in all but the shrub canopy microsite. Soil at this depth and microsite was found to be statistically similar to surface soils after the burn (Fig. 1).

\section{Final Infiltration and Saturated Hydraulic Conductivity Rates}

Preburn soil infiltration rates were greatest on the lower elevation (2 $103 \mathrm{~m}$ ) study site (Table 4). Extremely coarse soil prevented ponding of water on the soil surface in most cases and, for this reason, the study site at $2103 \mathrm{~m}$ was not included in the statistical analyses. After the burn, the infiltration of water into soils was reduced on all the different vegetative cover types at $2103 \mathrm{~m}$ (Table 4). However, because there was little preburn numeric data for comparison the results are strictly observational.

Final infiltration rates were affected by microsite, treatment, treatment $\times$ microsite interactions, and treatment $\times$ elevation $\times$ microsite interactions (Table 5). Final infiltration rates on the intermediate elevation (2 $225 \mathrm{~m})$ study site were affected by microsite and treatment (Fig. 2; Table 4). Before the burn, interspace and shrub microsites had final infiltration rates less
Table 5. ANOVA results for final infiltration and saturated hydraulic conductivity $\left(\mathrm{K}\left[\theta_{\mathrm{s}}\right]\right)$ rates of pinyon-juniper soils subjected to prescribed burning at different elevations and under different vegetation cover (microsites).

\begin{tabular}{|c|c|c|c|c|c|c|}
\hline \multirow[b]{2}{*}{ Factor } & \multicolumn{3}{|c|}{$\begin{array}{c}\text { Final } \\
\text { infiltration rate }\end{array}$} & \multicolumn{3}{|c|}{$\begin{array}{c}\text { Saturated hydraulic } \\
\text { conductivity }\end{array}$} \\
\hline & $\mathrm{df}^{1}$ & $\mathrm{~F}$ & $P$ & $d f^{1}$ & $\mathrm{~F}$ & $P$ \\
\hline Elevation & 1 & 3.22 & 0.1471 & 1 & 5.02 & 0.0887 \\
\hline Replicate (elevation) & 4 & & & & & \\
\hline Microsite & 3 & 10.10 & 0.0023 & 3 & 8.9 & 0.0036 \\
\hline Elevation $\times$ microsite & 2 & 0.52 & 0.6104 & 2 & 0.78 & 0.4857 \\
\hline Microsite $\times$ replicate (elevation) & 10 & & & & & \\
\hline Treatment & 1 & 38.45 & $<0.0001$ & 1 & 8.19 & 0.0061 \\
\hline Treatment $\times$ microsite & 3 & 14.96 & $<0.0001$ & 3 & 3.31 & 0.0272 \\
\hline Treatment $\times$ elevation & 1 & 1.81 & 0.1797 & 1 & 0.38 & 0.5383 \\
\hline Treatment $\times$ elevation $\times$ microsite & 2 & 7.20 & 0.0009 & 2 & 1.15 & 0.3243 \\
\hline $\begin{array}{l}\text { Treatment } \times \text { microsite } \times \\
\quad \text { replicate (elevation) }\end{array}$ & 51 & & & & & \\
\hline
\end{tabular}

${ }^{1}$ Degree of freedom.

than tree microsites. After the burn, shrub and interspace microsites retained comparably low infiltration rates. Tree canopy microsites in high tree-dominance stands, however, were no longer statistically different than any other microsite, and intermediate tree-dominance microsites were similar to shrub microsites (Table 4; Fig. 2).

At the highest elevation $(2347 \mathrm{~m})$ study site, the final infiltration rates were affected by microsite (i.e., cover) but not by burning treatment (Table 4; Fig. 2). Interspace microsites had the lowest final infiltration rate before and after the burn, but were only statistically different than tree canopy microsites.

Estimated $K\left(\theta_{\mathrm{s}}\right)$ rates were similar to the mean final infiltration rates in most cases. However, a separate comparative analysis was warranted because the calculated $K\left(\theta_{\mathrm{s}}\right)$ rate values are not a direct transformation of the final infiltration rates $\left(\mathrm{i}_{\mathrm{f}},{ }\right)$ but are instead based on cumulative final infiltration rate $\left(\mathrm{I}_{\mathrm{f}}\right)$.

The low number of data points on the lower elevation (2 $103 \mathrm{~m}$ ) study site again rendered statistical comparisons impossible. However, the observations suggest that large decreases in $K\left(\theta_{\mathrm{s}}\right)$ rates occurred after the fire on all of the microsites at this elevation (Table 4).

$\mathrm{K}\left(\theta_{\mathrm{s}}\right)$ rate is affected by microsite, treatment, and treatment $\times$ microsite interactions (Table 5). At the intermediate elevation (2 $225 \mathrm{~m}$ ) study site $\mathrm{K}\left(\theta_{\mathrm{s}}\right)$ rates were affected by microsite and treatment. The soils on microsites beneath tree canopies had statistically greater $K\left(\theta_{\mathrm{s}}\right)$ rates than soils under interspace and shrub vegetation before the burn, but following the burn no differences in $K\left(\theta_{\mathrm{s}}\right)$ rates were present among the vegetative cover types (Table 4 ).

For the high-elevation $(2347 \mathrm{~m})$ study site, all microsites were statistically similar before the burn, but after the burn interspace microsites differed from tree canopy microsites (Table 4).

Figure 2. Mean infiltration rates $\left(\mathrm{mm} \cdot \mathrm{min}^{-1}\right)$ and standard errors over time for interspace, undershrub canopy, and undertree canopy microsites on intermediate (int.) tree-dominance plots at $2225 \mathrm{~m}$ and $2347 \mathrm{~m}$, and for undertree canopy microsites on high tree-dominance plots at $2225 \mathrm{~m}$. 
Elevation 2225 m
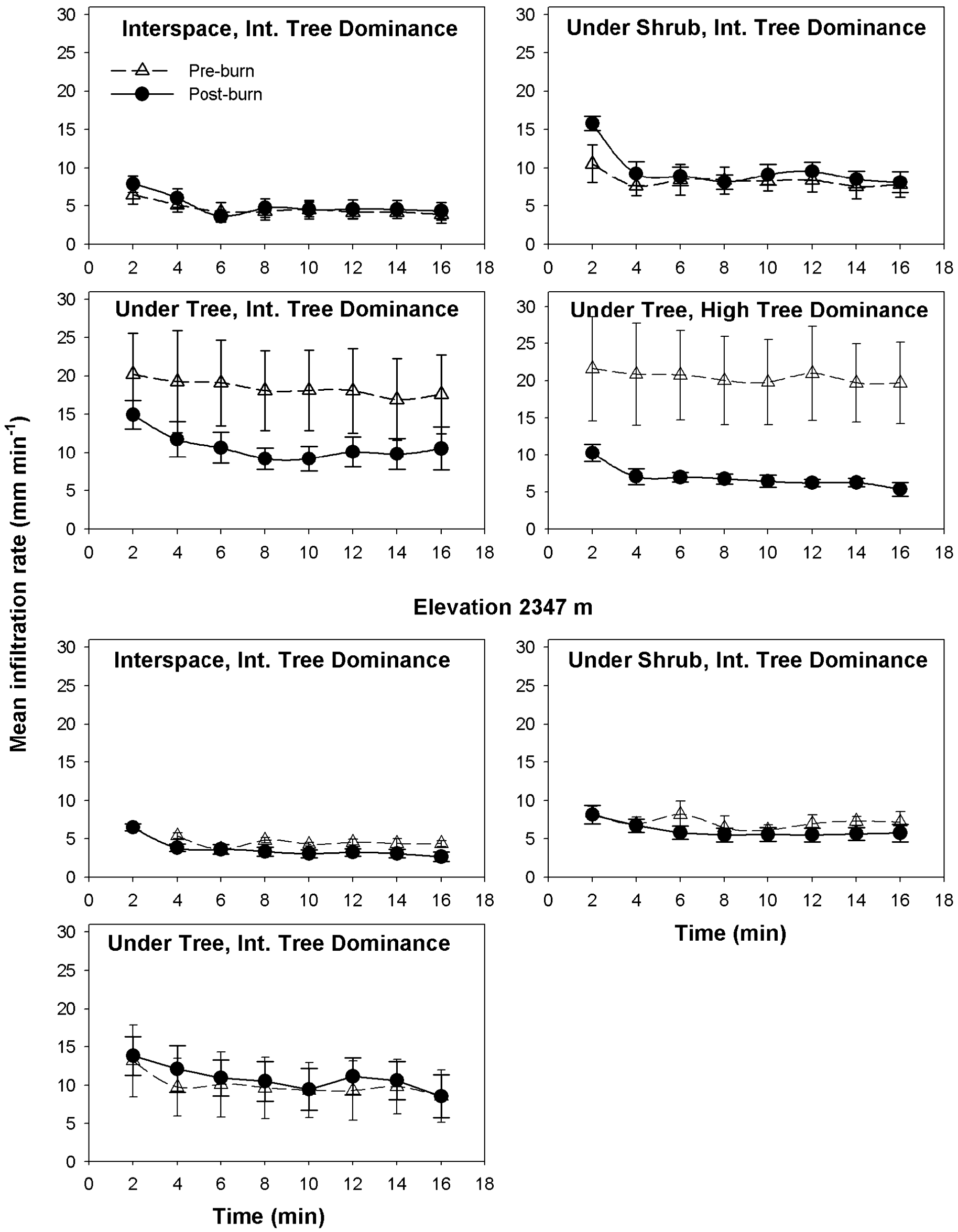

Time (min) 


\section{DISCUSSION}

\section{Soil Heating and Water Repellency}

Water repellency following prescribed fire was affected by soil texture and soil heating. Surface soil coarse fragment $(0-15 \mathrm{~cm})$ increased with decreasing elevation $(P=0.0004$, degrees of freedom $[\mathrm{df}]=2,12)$. Fire behavior resulting from the different cover conditions (i.e., undertree and undershrub canopies and interspaces) affected soil heating and postfire water repellency patterns.

The differences in particle size distribution among the 3 study sites over the elevation gradient most likely resulted from the localized variation in climate. Although only $244 \mathrm{~m}$ in elevation separated the lower and upper elevation study sites, the temperature and precipitation regimes were dramatically different. The average annual precipitation ranges from $230 \mathrm{~mm}$ at the bottom of the watershed to $500 \mathrm{~mm}$ at the top of the drainage and snow frequently accumulates at the higher elevations because of cooler temperatures (USDA Forest Service RMRS Reno, Nevada, unpublished data). Over time these differences in climate have resulted in differential soil development and the differences in soil texture measured at the different study sites. In general, the percentage of $>2 \mathrm{~mm}$ and silt-sized mineral soil particles decreased with elevation compared to percent clay and sand-sized mineral particles, which increased (Table 1). For example, about $74 \%$ of the surface soil at the lower elevation $(2103 \mathrm{~m})$ study sight was made up of particles $>2 \mathrm{~mm}$, and $53 \%$ of the $<2 \mathrm{~mm}$ mineral soil particles were sand-sized particles. These coarse textured soils not only affected water repellency, but also interfered with the infiltration trials. In contrast, the surface soil at the higher elevation $(2347 \mathrm{~m})$ study site contained only about $43 \%$ of particles $>2 \mathrm{~mm}$, and almost $8 \%$ of the $<2 \mathrm{~mm}$ mineral soil particles were made up of clay (Table 1). Variation in coarse fragment and soil-specific surface area affects the development of water repellency (DeBano et al. 1970).

During the spring prescribed burn maximum soil temperatures measured with temperature-sensitive paints indicated that soil heating was generally limited to less than $5 \mathrm{~cm}$ soil depth, and that soil heating was greatest under the shrub canopies both at the soil surface and at the $2-\mathrm{cm}$ soil depth (Table 2). Soil heating occurred under the tree canopies at the soil surface and 2-cm depth, but maximum observed temperatures were less than undershrub canopies. In the interspace, microsite soil temperatures were raised only at the soil surface and that increase was less than occurred under either the shrub or tree canopies. Although sagebrush canopies burn at greater temperatures than understory vegetation (Neary et al. 1999), they do not support a substantial litter layer $(<5 \mathrm{~cm})$ as compared to that found under pinyon tree canopies $(6-10 \mathrm{~cm})$ (Reiner 2004). At the time of the prescribed fire, the gravimetric fuel moisture content of the thicker surface litter layers under the pinyon trees was high $(\approx 45 \%)$ and insulated the soil at the 2-cm depths or greater from the intense soil heating that occurred under the flaming sagebrush canopies (Table 2) (USDA Forest Service Humboldt Toiyabe National Forest, unpublished data, 2004). Insulation of the soil surface from intense heating may not occur if prescribed burning occurs in the fall. Fuel moisture is typically lower during fall burns and litter mats may be completely consumed, resulting in more intense soil heating under tree canopies.

Water repellency is a common phenomenon found in soils of arid regions (both burned and unburned conditions) because the hydrophobic substances that produce water repellency can be stored in the litter on the soil surface until they are either leached downward by water on unburned sites or are volatilized and moved downward in the soil during a fire (Parks and Cundy 1989; Brock and DeBano 1990; Covington and DeBano 1990). In this study, the water repellency produced after the fire differed among the 3 study sites. At the highest elevation (2 $347 \mathrm{~m}$ ), there was only minimal water repellency produced as a result of the fire. This may have occurred because of the low content $(42 \%)$ of coarse mineral particles $>2 \mathrm{~mm}$ in the soils found on this site. Soils having smaller particle sizes and greater specific surface areas are generally less susceptible to becoming water repellent than coarser textured soils because they do not allow the organic distillate to penetrate as deeply into the soil. Those substances that do penetrate do not effectively coat the larger surface area of the mineral particles (DeBano et al. 1970; Brock and DeBano 1990). The soils collected from the $0-3 \mathrm{~cm}$ depth on the midelevation $(2225 \mathrm{~m}$ ) study site immediately before the burn were found to be slightly water repellent or not water repellent (Fig. 1), similar to observations by Robichaud and Hungerford (2000). However, following the burn, the surface soils on all of the microsites on the midelevation (2 $225 \mathrm{~m}$ ) study site were found to be more water repellent (Fig. 1). The only subsurface soil layer $(3-8 \mathrm{~cm})$ affected by fire was undershrub canopies (Fig. 1). At this microsite, the maximum soil temperature measurements at the $2-\mathrm{cm}$ depth were the highest that were measured during the study (Table 2). This intense soil heating under the shrub canopy most likely produced large temperature gradients that moved volatilized hydrophobic substances more deeply in the soil profile (DeBano et al. 1976; DeBano 2000).

\section{Final Infiltration and Saturated Hydraulic Conductivity Rates}

Before the prescribed burn (in 2001), the soil differences among the study sites at the 3 different elevations made it difficult to successfully measure infiltration and hydraulic conductivity rates. For example, the lower elevation study site $(2103 \mathrm{~m})$ contained a high proportion of $>2 \mathrm{~mm}$ particles $(74 \%)$, making it nearly impossible to pond water on the surface during the infiltration trials (Table 1). Therefore, the few infiltration tests that were completed were made only in the interspaces ( 2 tests) and undershrub canopies (1 test), but not undertree canopies (Table 4). These tests did not provide enough numerical data to include into the statistical analyses. Although the surface soils at the intermediate elevation $(2225 \mathrm{~m})$ study site were coarse-textured and were made up of about $60 \%$ of particles $>2 \mathrm{~mm}$ (Table 1), it was possible to determine both final infiltration rates and hydraulic conductivity rates (Fig. 2; Table 4). On these intermediate elevation study sites, both the final infiltration and hydraulic conductivity rates were greater under the tree canopies than undershrub canopies and in interspaces (Fig. 2; Table 4). Tree dominance did not affect final infiltration or $\mathrm{K}\left(\theta_{\mathrm{s}}\right)$ rates (Fig. 2; Table 4). 
On the higher elevation study site $(2347 \mathrm{~m})$, the final infiltration rates under the tree canopies were greater than in the interspaces, but those undershrub canopies were no different from tree canopy or interspace microsites (Fig. 2; Table 4). High spatial variability of infiltration and hydraulic conductivity rates (such as occurred at the different elevation and cover conditions in this study) has also been reported (Parks and Cundy 1989; Hester et al. 1997; Pierson et al. 2002). Some investigators suggest that this high heterogeneity could be a result of spatial variability in soil organic matter and root density between microsites (Hester et al. 1997; Davenport et al. 1998).

The effect of spring burning on the different study sites and microsites was highly variable. However, infiltration and $\mathrm{K}\left(\theta_{\mathrm{s}}\right)$ rates were reduced by burning at all microsites on the lower elevation $(2103 \mathrm{~m})$ study site and by burning under the tree canopies on the intermediate elevation $(2225 \mathrm{~m})$ study site (Fig. 2; Table 4). Tree dominance did not affect the response of undertree canopy microsites to burning. After the fire, final infiltration and $K\left(\theta_{s}\right)$ rates were less variable than before burning (Fig. 2), indicating that fire generally reduces the heterogeneity of landscapes in natural systems (Parks and Cundy 1989). The combined effect of soil surface pore space reduction by ash and the condensation of hydrophobic substances onto mineral surfaces appear to be the major mechanisms responsible for the reduced infiltration and $\mathrm{K}\left(\theta_{\mathrm{s}}\right)$ rates.

\section{MANAGEMENT IMPLICATIONS}

The results of this study indicate that spring prescribed burning in pinyon-juniper woodlands can affect soil hydrologic characteristics. However, spring burning may not affect landscape scale processes under certain lithologic and climatic conditions. We have shown that fire-induced water repellency can be spatially variable after spring prescribed burning, and it is therefore important that managers consider the soil characteristics, type and percentage cover of vegetation, and climate of the woodland with which they are dealing. Development of water-repellent soils is affected by elevation gradients due to differences in surface soil particle size distribution, especially coarse mineral particles (Table 1). Water repellency is also affected by spatial variability in surface and soil organic matter associated with the type of vegetation and its percentage canopy cover. Spring burning in sagebrush canopy microsites may have little or no effect on surface soil hydrology if the surface soil coarse mineral particles are less than $60 \%$. However, burning in pinyon canopy microsites may cause decreases in infiltration and $\mathrm{K}\left(\theta_{\mathrm{s}}\right)$ rates if the surface soil coarse mineral particles are greater than $40 \%$. The degree of tree dominance may not affect under tree canopy response to burning, but it will influence the percentage of the landscape affected by fire-induced water repellency. Fall burning may result in more widespread and intense soil heating because fuel and soil moisture are typically lower, resulting in greater development of water repellency (Robichaud and Hungerford 2000).

The effects of reduced infiltration, $\mathrm{K}\left(\theta_{\mathrm{s}}\right)$, and the development of water repellency must be considered in the context within which they occur. Soil with coarse mineral particles greater than $40 \%$ will likely have high infiltration and $K\left(\theta_{\mathrm{s}}\right)$ rates. The probability of a precipitation event exceeding $\mathrm{K}\left(\theta_{\mathrm{s}}\right)$ should decrease as $K\left(\theta_{\mathrm{s}}\right)$ increases within a climatic region.

Alluvial fans of Underdown Canyon in central Nevada are high in coarse mineral particles. Also, precipitation occurs predominantly as winter snow and spring rain, and obvious evidence of overland flow is lacking. High-intensity summer monsoon events are infrequent in contrast to areas in Arizona, Colorado, and New Mexico (Mohrle 2003). Saturated hydraulic conductivity data collected from this site and data from the National Oceanic and Atmospheric Administration indicate that the probability of a 5 -minute storm event intense enough to exceed the lowest levels of conductivity is $0.1 \%$ every year (http://dipper.nws.noaa.gov/hdsc/pfds/). It is therefore unlikely that prescribed fire in an area similar to Underdown Canyon will cause detrimental hydrologic response unless unusually high-intensity precipitation occurs.

\section{ACKNOWLEDGMENTS}

Authors wish to thank David Board and Dave Turner for assistance in statistical analyses.

\section{LITERATURE CITED}

BLACK, C. A. (EDITOR-IN-CHIEF). 1965. Soil Analysis. Part 1. Physical and Mineralogical Properties Including Statistics of Measurement and Sampling. Madison, WI: American Society of Agronomy Series 9. p 557-559.

Bouwer, H. 1986. Intake Rate: Cylinder Infiltrometer. Methods of Soil Analyses, part 1. Physical and Mineralogical Methods-Agronomy Monograph No. 9. 2nd ed. Madison, WI: Soil Science Society of America. p 825-844.

Brock, J. H., and L. F. DeBano. 1990. Wetability of an Arizona chaparral soil influenced by prescribed burning. In: J. S. Krammes [TECH. COORD.]. Proceedings of a Symposium on the Effects of Fire Management of Southwestern Natural Resources; 14-17 November 1988; Tucson, AZ. Fort Collins, C0: USDA Forest Service, Rocky Mountain Forest and Range Experiment Station General Technical Report RM-191. p 206-209.

BUCKHOUSE, J. C., AND G. F. GIFFORD. 1976. Sediment production and infiltration rates affected by grazing and debris burning on chained and seeded pinyon-juniper. Journal of Range Management 29:83-85.

Cannon, S. H., P. S. Powers, and W. Z. Savage. 1998. Fire-related hyper concentrated and debris flows on Storm King Mountain, Glenwood Springs, Colorado, USA. Environmental Geology 35(2-3):210-218.

Chambers, J. C. 2001. Pinus monophylla establishment in expanding PinusJuniperus woodland: environmental conditions, facilitation and interacting factors. Journal of Vegetation Science 12:27-40.

Covington, W. W., and L. F. DeBano. 1990. Effects of fire on pinyon-juniper soils. In: J. S. Krammes [TECH. COORD.]. Proceedings of a Symposium on the Effects of Fire in Management of Southwestern Natural Resources; 14-17 November 1988; Tucson, AZ. Fort Collins, CO: USDA Forest Service, Rocky Mountain Forest and Range Experiment Station General Technical Report RM-191. p 7886.

Davenport, D. W., D. D. Breshears, B. P. Wilcox, and C. D. Allen. 1998. Viewpoint: sustainability of piñon-juniper ecosystems-a unifying perspective of soil erosion thresholds. Journal of Range Management 51:231-240.

DuRGIN, B. D. 1985. Burning changes erodibility of forest soils. Journal of Soil and Water Conservation 40:299-301.

DeBano, L. F. 2000. The role of fire and soil heating on water repellency in wildland environments: a review. Journal of Hydrology 231-232:195-206.

DeBano, L. F., L. D. Mann, and D. A. Hamilton. 1970. Translocation of hydrophobic substances into soil by burning organic matter. Soil Science Society of America Proceedings 34:130-134.

DeBano, L. F., S. M. Savage, and D. A. Hamilton. 1976. The transfer of heat and 
hydrophobic substances during burning. Soil Science Society of America Proceedings 40:779-783.

GrueLL, G. E. 1999. Historical and modern roles of fire in pinyon-juniper. In: S. B. Monsen and R. Stevens [CoMPS.]. Proceedings: Ecology and management of pinyon-juniper communities in the interior west. Proceedings RMRS-P-9. Ogden, UT: USDA Forest Service, Rocky Mountain Research Station. p 24-28.

Hester, J. W., T. L. ThuRow, and C. A. TayloR. 1997. Hydrologic characteristics of vegetation types as affected by prescribed burning. Journal of Range Management 50:199-204.

ILLG, C., AND G. ILLG. 1997. Forest fire, water quality, and the incident at Buffalo Creek. American Forests 103(1):33-35.

Korfmacher, J. L., J. C. Chambers, R. J. Tausch, B. A. Roundy, S. E. Meyer, and S. KITCHEN. 2002. Technical note: a technique for conducting small-plot burn treatments. Journal of Range Management 56:251-254.

LETEY, J. 1969. Measurement of the contact angle, waterdrop penetration time, and critical surface tension. In: L. F. DeBano and J. L. Letey [EDS.]. Proceedings of the Symposium on Water Repellent Soils; 6-10 March 1968; Riverside, CA. Riverside, CA: University of California. p 43-47.

Milzer, R. F., AND J. A. Rose. 1995. Historic expansion of Juniperus occidentalis (western juniper) in southern Oregon. Great Basin Naturalist 55:37-45.

MILleR, R. F., AND J. A. Rose. 1999. Fire history and western juniper encroachment in sagebrush steppe. Journal of Range Management 52:550-559.

Miller, R. F., and R. J. Tausch. 2001. The role of fire in juniper and pinyon woodlands: a descriptive analysis. In: K. E. M. Gallet and T. P. Wilson [EDs.]. Proceedings of the Invasive Species Workshop: The Role of Fire in the Control and Spread of Invasive Species. Tallahassee, FL: Tall Timbers Research Station Miscellaneous Publications No. 11. p 15-30.

Miller, R. F., and P. E. Wigand. 1994. Holocene changes in semi arid pinyonjuniper woodlands: response to climate, fire, and human activities in the U.S. Great Basin Bioscience 44:465-474.

MohrLE, C. H. 2003. The Southwest monsoon and the relation to fire occurrence [master's thesis]. Reno, NV: University of Nevada Reno.

Neary, D. G., C. C. Klopatek, L. F. DeBano, and P. F. Ffolliott. 1999. Fire effects on belowground sustainability: a review and synthesis. Forest Ecology and Management. 122:51-71.

Parks, D. S., AND T. W. Cundy. 1989. Soil hydraulic characteristics of a small
Southwest Oregon watershed following high-intensity wildfire. USDA Forest Service General Technical Report PSW-109:63-67.

Pierson, F. B., D. H. Carlson, and K. E. Spaeth. 2002. Impacts of wildfire on hydrological properties of steep sagebrush-steppe rangeland. International Journal of Wildland Fire 11:145-151.

Pierson, F. B., K. E. Spaeth, and D. H. Carlson. 2001. Fire effects on sediment and runoff in steep rangeland watersheds. In: Proceedings of the Seventh Federal Interagency Sedimentation Conference; 25-29 March 2001; Reno, Nevada. Federal Interagency Project, Technical Committee of the Subcommittee on Sedimentation. $\mathrm{p}$ X-33-X-40.

Poff, R. J. 1989. Distribution and persistence of hydrophobic soil layers on the Indian Burn. In: N. H. Berg [TECH. COORD.]. Proceedings of the Symposium on Fire and Watershed Management; 26-28 October 1988; Sacramento, CA. Berkeley, CA: USDA Forest Service, Pacific Southwest Forest and Range Experiment Station Technical Report PSW-109. p 153.

ReINER, A. L. 2004. Fuel load and understory community changes associated with varying elevation and pinyon-juniper dominance [master's thesis]. Reno, NV: University of Nevada Reno.

Robichaud, P. R., and R. D. Hungerford. 2000. Water repellency by laboratory burning of four Northern Rocky Mountain forest soils. Journal of Hydrology 231-232:207-219.

SAS InStituTE. 2004. SAS 9.1 user's guide. Copyright 2004. Cary, NC: SAS Institute Inc.

TAusch, R. J. 1999a. Historic woodland development. In: S. B. Monsen and R. Stevens [comps.]. Proceedings: Ecology and management of pinyon-juniper communities in the interior west. Ogden, UT: Proceedings RMRS-P-9, USDA Forest Service, Rocky Mountain Research Station. p 12-19.

TAUSCH, R. J. 1999b. Transitions and thresholds: influences and implications for management in pinyon and Utah juniper woodlands. In: S. B. Monsen and R. Stevens [comps.]. Proceedings: Ecology and management of pinyon-juniper communities in the interior west. Ogden, UT: Proceedings RMRS-P-9, USDA Forest Service, Rocky Mountain Research Station. p 61-65.

Ulery, A. L., and R. C. Graham. 1993. Forest fire effects on soil color and texture. Soil Science Society of America Journal 57:135-140.

Ulery, A. L., R. C. Graham, and L. H. Bowen. 1996. Forest fire effects on soil phyllosilicates in California. Soil Science Society of America Journal 60:309315. 